\title{
Impact of Tillage Intensity, NPK Fertilization and Weed Control on Seed Yield and Yield Components of Flaxin Newly Reclaimed Lands
}

\author{
A. I. Nawar, Kh. A. Abou-zied** and H. E. Khalil** \\ Crop Science Department, Faculty of Agriculture, Alexandria University; *Weed Research \\ Central Laboratory, Agricultural Research Center and ${ }^{*}$ Crop Intensification Department, \\ Field Crop Research Institute, Agricultural Research Center, Giza, Egypt.
}

CAKHA 4 flax (Linum usitatissmum L.) cultivar was grown in 2013/14 and 2014/15 winter seasons to study the effect of two tillage systems (conventional tillage (CT) vs no-tillage (NT)), macronutrients fertilization (NPK, NP and P) and weed control treatments, i.e. Brominal + Select super, Sinal + Select super, hand weeding twice and unweeded check on weeds and flax productivity at Nubaria Research Station, Agricultural Research Center. The experimental design was split split-plot with 4 replications.

Total weeds fresh weight was lower significantly in NT than CT by 17.0 and $18.4 \%$, in the two seasons, respectively. Application of NPK gave higher total weeds fresh weight than NP or P by 6.3 and $20.6 \%$ and 8.4 and $20.0 \%$, in the two seasons, respectively, while NP superior P by 15.2 and $12.7 \%$, in the two seasons, respectively. Brominal + Select super was more effective in reducing total weeds fresh weight (98.1 and 97.1\%) than Sinal + Select super (92.6 and 92.4\%) and hand weeding (93 and 90.7\%) compared to unweeded check during the two seasons regardless of the tillage system.

No-tillage gave comparable seed yield (1363.7 and $1464.2 \mathrm{~kg} / \mathrm{ha})$ to conventional tillage $(1562.0$ and $1530.1 \mathrm{~kg} / \mathrm{ha})$ in the two seasons, respectively. NPK fertilization gave higher values for plant height, number of capsules per plant, 1000-seed weight and straw yield. NPK and NP fertilization increased the seed yield by 57.1 and $51.4 \%$ and 69.1 and $50.7 \%$, in the two seasons, respectively, compared to P fertilization treatments.

All weed control treatments gave significantly higher values for seed yield and yield components compared to unweeded check, with Brominal + Select super giving a slight increase in the values of those characters compared to Sinal + Select super. Percent increase in seed yield, over control was 71,69 and $68.5 \%$ and $68,67.5$ and $68.4 \%$, for the two seasons, respectively. Correlation analysis revealed negative effect of weeds on flax growth and productivity.

The present study indicated that no-tillage was equivalent to conventional tillage concerning productivity of seed and straw from dual purpose flax (for oil and fiber), and the necessity of a balanced fertilization program with macronutrients, in association with post-emergence herbicides application to realize high yields.

Keywords: Tillage, NPK fertilization, Weed control and flax.

\section{Introduction}

Flax (Linum usitatissmum L.) is grown as a dual purpose crop in Egypt, i.e. for production of fibers and oil. The area devoted for flax production gradually decreased during the last decade to reach 7385 faddans in 2014/2015. That decrease in cultivated area is primarily attributed to increase in production costs, especially inputs related to land preparation and manual labor wages for hand weeding and harvesting. However, production costs could be reduced in the newly reclaimed lands by implementation of no-tillage and application of integrated weed managements for weed control.

No-tillage (NT or zero tillage) is a component of conservation agriculture (CA) system, in which seeds are placed into untilled soil by opening a narrow slot, trench, or hole of only sufficient width and depth to obtain proper seed placement and coverage (Derpsch et al., 2014). The

\#Corresponding authoer email: dr.khaled_nubaria@yahoo.com

DOI :10.21608/agro.2017.1022.1063

C2017 National Information and Documentation Center (NIDOC) 
environmental and economic benefits of no-tillage include reducing wind and soil erosion (Verhulst et al., 2010), improvement of soil structure and enhancing biological activity, nutrient cycling, soil water holding capacity (Hobbs et al., 2008 and Verhulst et al., 2010) and reduce production costs, often attributed to decreases in energy and labor consumption (Ernestein et al., 2012) compared to conventional tillage (CT). Meanwhile, adoption of no-tillage system will change weed communities and growth dynamics, compared to under conventional tillage system, thus weed control via herbicides need to be adjusted (Nichols et al., 2015). Mankowski et al. (2013) reported that no-tillage, regardless of weed control, reduced the number and weight of weeds compared to conventional cultivation with plowing. Moreover, Mankowski \& Pudelko (2015) found that weed control with herbicide, regardless of the tillage system, increased the yield of fiber, resulting from both the increase in straw yield and the share of fiber in the straw of flax. Blackshawet al. (2008) concluded the herbicides could be used, with targeted and limited use in conjunction with zero tillage for effective control of weeds. Many studieswere recommended several herbicides as effective control methods against broad-leaved weeds, such as Granstar (Mousa, 2002 and Osman et al., 2010). However, Abd-El-Samie \& Abd-ElDayem (2000) and Osman et al. (2010) found, in divergent studies, that Fusilade showed effective weed control against grass weeds, compared to unweeded check treatment.

Application of macronutrients, i.e. nitrogen, phosphorus and potassium, is essential for enhancing flax growth and productivity. Several researchers reported on the beneficial application of nitrogen (Dordas, 2010 and Ruisi et al., 2016), phosphorus (El-Deeb et al., 2006) and potassium (Bakry et al., 2015) either individually or in combination of NP (Lafond et al., 2003) or NPK (Leilah et al., 2003 and Khajani et al., 2012) on productivity of fiber and oil in flax. However, most of the published research reports data were under minimal or zero tillage systems. No-tillage as previously mentioned has an impact on soil structure, compared to conventional tillage, which will change distribution of plant nutrients in the soil profile, nutrient availability and fertilizer management decisions (Grant et al., 2008).

The present investigation was designed to study the role of tillage system, macronutrients application and weed control on growth and productivity of flax cultivar Sakha 4 and associated annual weeds.

\section{Materials and Methods}

Two field experiments were carried out in the winter seasons of 2013/2014 and 2014/2015 at the experimental farm of Nubaria Research Station, Agricultural Research Center, Beheira Governorate. Physical and chemical properties of the soil at the experimental site are presented in Table 1 as an average of the two seasons. The objectives of the investigation were to study the effect of tillage system, macronutrients fertilization and weed control treatments on growth and productivity of flax cultivar Sakha 4 and on annual weeds. The design used was split split-plot with four replications. Each sub sub-plot comprised 20 rows, $15 \mathrm{~cm}$ apart and $3 \mathrm{~m}$ in length as follow:

\section{A- Main plots: (Tillage system) \\ 1- Conventional tillage. \\ 2- No-tillage. \\ $B$-Sub plots: (Macronutrients fertilization) \\ 1- NPK. \\ 2- NP. \\ 3- P. \\ C-Sub-sub plots: (Weed control treatments) \\ 1-Brominal + Select super. \\ $2-$ Sinal + Select super. \\ 3-Handweeding twice. \\ 4-Unweeded check (control).}

The common and trade names, as well as chemical family, mode of action, time of application and targeted weeds for the used herbicides are presented in Table 2.

Conventional tillage was performed as two ploughings by chisel plough, whereas in no-tillage, no ploughing was applied and weeds of previous season were removed by hand cutting. Phosphorus (P) and potassium (K) were applied during soil preparation in conventional tillage and on top of soil surface followed directly by irrigation in no-tillage at the rate of $150 \mathrm{~kg} /$ faddan of mono super phosphate $\left(15.5 \% \mathrm{P}_{2} \mathrm{O}_{5}\right)$ and $24 \mathrm{~kg} /$ faddan potassium sulphate $\left(\begin{array}{llll}48 & \% & \mathrm{~K}_{2} \mathrm{O}\end{array}\right)$, respectively. Nitrogen was applied in the form of ammonium nitrate $(33.5 \% \mathrm{~N})$ at the rate of $60 \mathrm{~kg} \mathrm{~N} /$ faddan in two equal doses, at second and third irrigations, in the two tillage systems by drilling.

The herbicides treatments were sprayed with a CP3 knapsack sprayer equipped with one nozzle boom with 200 liters of water/fad.Flax seeds were hand-drilled on November 8 and 15 in the first and second season, respectively, at the rate of $50 \mathrm{~kg} /$ faddan. 
TABLE 1. Physical, chemical and mechanical properties of the soil at experimental site, as an average of the two seasons.

\begin{tabular}{lccccccccccc}
\hline Characters & $\begin{array}{c}\mathbf{E C} \\
\mathbf{d S} / \mathbf{m}\end{array}$ & $\begin{array}{c}\mathbf{p H} \\
\mathbf{1 : 2 . 5}\end{array}$ & $\mathbf{C a C O}_{\mathbf{3}} \mathbf{0}$ & $\begin{array}{c}\text { Organic } \\
\text { matter\% }\end{array}$ & $\begin{array}{c}\mathbf{N} \\
(\mathbf{p p m})\end{array}$ & $\begin{array}{c}\mathbf{P}_{2} \mathbf{O}_{\mathbf{5}} \\
(\mathbf{p p m})\end{array}$ & $\begin{array}{c}\mathbf{K} \\
(\mathbf{p p m})\end{array}$ & \multicolumn{2}{c}{ Mechanical analysis } & $\begin{array}{c}\text { Soil } \\
\text { texture }\end{array}$ \\
\hline Analysis & 2.30 & 8.11 & 24.12 & 0.41 & 42.13 & 3.92 & 174 & 53.26 & 24.13 & 22.61 & $\begin{array}{c}\text { Sandy } \\
\text { loam }\end{array}$ \\
\hline
\end{tabular}

TABLE 2. Common and trade names, chemical family, mode of action, time of application and targeted weeds for the used herbicides.

\begin{tabular}{|c|c|c|c|c|}
\hline $\begin{array}{c}\text { Common and Trade } \\
\text { name }\end{array}$ & Chemical Family & Mode of Action & Time of application & Targeted weeds \\
\hline $\begin{array}{l}\text { Bromoxynil } \\
\text { (Brominal } \\
24 \% \text { EC) }\end{array}$ & Nitriles & $\begin{array}{l}\text { Inhibition of } \\
\text { photosynthesis } \\
\text { atphotosystem II }\end{array}$ & $\begin{array}{l}\text { Post-emergence at } \\
3-5 \text { leaves stage. }\end{array}$ & $\begin{array}{l}\text { Broad-leaved } \\
\text { weeds }\end{array}$ \\
\hline $\begin{array}{l}\text { Metosulam } \\
(\text { Sinal10 \% SC) }\end{array}$ & Triazolopyrimidines & $\begin{array}{l}\text { Inhibition of } \\
\text { acetolactate } \\
\text { synthase ALS } \\
\text { (acetohydroxyacid } \\
\text { synthase AHAS) }\end{array}$ & $\begin{array}{l}\text { Post - emergence at } \\
3-5 \text { leaves stage. }\end{array}$ & $\begin{array}{l}\text { Broad-leaved } \\
\text { weeds }\end{array}$ \\
\hline $\begin{array}{l}\text { Clethodim } \\
\text { (Select super } \\
12.5 \% \text { EC) }\end{array}$ & $\begin{array}{l}\text { Cyclohexanediones } \\
\text { 'DIMs' }\end{array}$ & $\begin{array}{l}\text { Inhibition of acetyl } \\
\text { CoA carboxylase } \\
\text { (ACCase) }\end{array}$ & $\begin{array}{l}\text { Post }- \text { emergence } \\
\text { after } 30 \text { days from } \\
\text { sowing }\end{array}$ & Grass weeds \\
\hline
\end{tabular}

After 60 days from sowing, weeds were hand pulled from one square meter taken at random from each sub sub-plot. Weeds were classified into broadleaved and grassy weeds and fresh weight of each category and total weeds were recorded. Annual weed species prevalent at the experimental site included broad-leaved weeds (Brassica tournefortii, Cichorium endivia, Medicago polymorpha and Vicia sativa) and narrow-leaved (grassy) weeds (Avena fatua, Lolium temulentum and Phalaris paradoxa).

At harvest, representative samples of 20 plants were randomly taken from every experimental unit to determine flax growth aspects of plant height (cm), technical length $(\mathrm{cm})$, fruiting zone length (cm) and number of basal and apical branches/plant in addition to number of capsules/plant and 1000 seed weight. The inner ten rows were harvested to calculate the seed and straw yields for each sub plot then converted to yields $(\mathrm{kg} / \mathrm{ha})$.

Economic analysis, and his effect on flax crop profitability, was done to investigate the variances between the different studied factors to get the highest profitability by using some economic criteria such as gross income, net income and profitability. Economic criteria were used according to the methods described by Heady \& Dillon (1961) and were estimated from the following formulas:

1-Gross income $(\mathrm{GI})=$ the price of straw yield + the price of seed yield.

2-Net income $(\mathrm{NI})=$ Gross income - Total costs.

3-Profitability $(\operatorname{Pr})=.($ Net income/Total costs $) \times 100$.

4-Benefit/Costs Ratio $(\mathrm{B} / \mathrm{C})=$ Gross income/Total costs.

Statistical analysis of data was conducted according to Gomez \& Gomez (1984) using SAS (Statistical Analysis System) ver. 9.01by computer. 


\section{Results and Discussion}

Effect of tillage, fertilization and weed control treatments and their interactions on weeds biomass

No-tillage significantly reduced total fresh weight of weeds by 17.0 and $18.4 \%$ in the two seasons, respectively, compared to conventional tillage (Table 3). Moreover, fresh weight of broad-leaved weeds and fresh weight of grass weeds, were reduced with no-tillage system compared to conventional tillage, however, the differences were significant in the second season only. Blackshaw et al. (2001) found that weed community dynamics were most affected by yearto-year differences in environmental conditions followed by tillage intensity. Mankowski et al. (2013) reported that no-tillage reduced the number and weight of weeds compared to conventional cultivation with plowing. That could be explained by accumulation of seeds near the soil surface in no-tillage system, thus seeds are exposed to higher mortality risks through weather variability and predation (Blubaugh \& Kaplan, 2015) and less seedling establishment (Franke et al., 2007).

Application of all three macronutrients (NPK) gave significantly higher fresh weight of total weeds, and both categories of weeds, than application of phosphorus (P) alone (Table 3 ). Application of NPK gave higher total weeds fresh weight than NP or P by 6.3 and $20.6 \%$ and 8.4 and $20.0 \%$, in the two seasons, respectively. In addition, NP was superior than P by 15.2 and $12.7 \%$ in the two seasons, respectively. The combination of nitrogen and phosphorus (NP) gave similar values to NPK except total weeds fresh weight in the second season. This effect may be explained by the role of nitrogen in enhancing vegetative growth of plants, including weeds, especially in combination with other macronutrients, i.e. phosphorus and potassium.

These results indicate that, although fertilization with appropriate amounts of macronutrients may benefit flax growth and productivity, it will also encourage weeds growth and competition to crop plants. Thus a fertilization program for flax is needed, taking in consideration the amount and timing of fertilization, that will allow better use of applied nutrients by crop plants and minimize their availability to weed plants.

Application of mixtures of herbicides for broad and narrow-leaved weeds (Table 3), i.e.
Brominal + Select super or Sinal + Select super, significantly reduced total fresh weight of weeds by 98.1 and $92.6 \%$ in the first season and 97.1 and $92.4 \%$ in the second season, respectively and weed categories compared to unweeded check. Moreover, both herbicide mixtures were significantly more effective in controlling grass weeds in both seasons than hand weeding. Brominal + Select superadd was superior to hand weeding in controlling grass and total weeds in both seasons, in addition to broad-leaved weeds in the second season. Osman et al. (2010) reported that significant reduction in dry weight of broadleaved, grassy and total weeds with application of post-emergence herbicides. They added that the combinations between herbicides for broad-leaved and grassy weeds are essential for controlling both weed categories in the flax crop.

Tillage system $\mathrm{x}$ weed control treatments interaction (Table 4) was significant in both seasons, for reducing broad-leaved and total weeds fresh weight. The Brominal + Select super mixture significantly gave the lowest weeds biomass for total weeds in the two seasons, regardless of the tillage system, compared to hand weeding in reducing broad-leaved weeds biomass. No-tillage significantly reduced both broad-leaved and total weeds biomass in the two seasons. Naldewaja (2003) reported that successful conservation agriculture was highly dependent upon effective weed control.The recent development of highly active post-emergent-appliedherbicides provide for simple effective weed control for conservation tillage practices. Thomas et al. (2010) found that high herbicide/zero tillage system significantly reduced weed density compared to no herbicide/high tillage system in four seasons at two locations.

Fertilization $\mathrm{x}$ weed control treatments interaction was significant for broad-leaved, grass and total weeds, in the two seasons (Table 5). The effect of applied weed control treatments varied with fertilization by macronutrients, where Brominal + Select super treatment was superior than Sinal + Select super in reducing broad-leaved weeds biomass with NPK, NP and P fertilization, while both herbicide combinations were statistically similar in their effect on grass weeds biomass in the two seasons, at the three macronutrients fertilization treatments. With respect to total weeds biomass, both herbicidal combinations were similar in reducing fresh weight of total weeds with NPK and P treatments, but Brominal + Select super was superior at NP fertilization treatment, in the first season. 
TABLE 3. Means for fresh weight of weeds categories $\left(\mathrm{g} / \mathrm{m}^{2}\right)$ as affected by tillage system, fertilization and weed control treatments in the two seasons.

\begin{tabular}{|c|c|c|c|c|c|c|}
\hline \multirow[b]{2}{*}{ Treatments } & \multicolumn{3}{|c|}{$2013 / 2014$} & \multicolumn{3}{|c|}{$2014 / 2015$} \\
\hline & $\begin{array}{l}\text { Broad- } \\
\text { leaved } \\
\text { weeds }\end{array}$ & $\begin{array}{l}\text { Grass } \\
\text { weeds }\end{array}$ & $\begin{array}{c}\text { Total } \\
\text { weeds }\end{array}$ & $\begin{array}{l}\text { Broad- } \\
\text { leaved } \\
\text { weeds }\end{array}$ & $\begin{array}{l}\text { Grass } \\
\text { weeds }\end{array}$ & $\begin{array}{c}\text { Total } \\
\text { weeds }\end{array}$ \\
\hline \multicolumn{7}{|l|}{ Tillage $(\mathrm{T})$} \\
\hline - $\quad$ No tillage (NT) & $64.5 \mathrm{a}$ & $68.6 \mathrm{a}$ & $133.1 \mathrm{~b}$ & $77.9 \mathrm{~b}$ & $75.8 \mathrm{~b}$ & $153.7 \mathrm{~b}$ \\
\hline \multicolumn{7}{|l|}{ Fertilization $(\mathrm{F})$} \\
\hline - NPK & $80.6 \mathrm{a}$ & $80.6 \mathrm{a}$ & $161.2 \mathrm{a}$ & $96.6 \mathrm{a}$ & $92.3 \mathrm{a}$ & $188.9 \mathrm{a}$ \\
\hline \multicolumn{7}{|l|}{ Weed control (W) } \\
\hline - $\quad$ Brominal + Select super & $5.17 \mathrm{c}$ & $4.25 \mathrm{c}$ & $9.42 \mathrm{c}$ & $7.29 \mathrm{~d}$ & $9.50 \mathrm{c}$ & $16.8 \mathrm{c}$ \\
\hline$-\quad$ Sinal + Select super & $32.5 \mathrm{~b}$ & $4.63 \mathrm{c}$ & $37.2 \mathrm{~b}$ & $32.1 \mathrm{~b}$ & $11.4 \mathrm{c}$ & $43.5 \mathrm{~b}$ \\
\hline - $\quad$ Hand weeding & $7.46 \mathrm{c}$ & $27.2 \mathrm{~b}$ & $34.7 \mathrm{~b}$ & $19.2 \mathrm{c}$ & $33.7 \mathrm{~b}$ & $52.9 \mathrm{~b}$ \\
\hline - $\quad$ Unweeded check & $255.6 \mathrm{a}$ & $250.0 \mathrm{a}$ & $505.6 \mathrm{a}$ & $295.1 \mathrm{a}$ & $275.7 \mathrm{a}$ & $570.8 \mathrm{a}$ \\
\hline \multicolumn{7}{|l|}{ Interactions: } \\
\hline$-\quad \mathrm{T} * \mathrm{~F}$ & ns & ns & ns & ns & $*$ & $*$ \\
\hline
\end{tabular}

TABLE 4. Means for tillage system * weed control treatments interaction effects on fresh weight $\left(\mathrm{g} / \mathrm{m}^{2}\right)$ of broadleaved and total weeds and number of capsules per plant.

\begin{tabular}{|c|c|c|c|c|c|c|}
\hline \multirow[b]{2}{*}{ Tillage } & \multirow{2}{*}{$\begin{array}{l}\text { Weed control } \\
\text { treatments }\end{array}$} & \multicolumn{2}{|c|}{ 2013/2014 } & \multicolumn{3}{|c|}{$2014 / 2015$} \\
\hline & & $\begin{array}{l}\text { Broad- } \\
\text { leaved } \\
\text { weeds }\end{array}$ & $\begin{array}{c}\text { Total } \\
\text { weeds }\end{array}$ & $\begin{array}{l}\text { Broad-leaved } \\
\text { weeds }\end{array}$ & $\begin{array}{c}\text { Total } \\
\text { weeds }\end{array}$ & $\begin{array}{c}\text { number of } \\
\text { capsules/ } \\
\text { plant }\end{array}$ \\
\hline \multirow{4}{*}{$\begin{array}{c}\text { Conventional } \\
\text { tillage(CT) }\end{array}$} & Brominal + Select super & $5.67 \mathrm{~d}$ & $10.0 \mathrm{~d}$ & $10.9 \mathrm{de}$ & $21.4 \mathrm{de}$ & $51.9 \mathrm{a}$ \\
\hline & Sinal + Select super & $39.7 \mathrm{c}$ & $45.8 \mathrm{~b}$ & $37.6 \mathrm{c}$ & $52.7 \mathrm{c}$ & $49.2 \mathrm{bc}$ \\
\hline & Hand weeding & $6.67 \mathrm{~d}$ & $36.7 \mathrm{~b}$ & $18.5 \mathrm{de}$ & $52.5 \mathrm{c}$ & $49.9 \mathrm{~b}$ \\
\hline & Unweeded check & $291.7 \mathrm{a}$ & $549.0 \mathrm{a}$ & $328.6 \mathrm{a}$ & $626.4 \mathrm{a}$ & $20.6 \mathrm{e}$ \\
\hline \multirow{4}{*}{ No tillage (NT) } & Brominal + Select super & $4.67 \mathrm{~d}$ & $11.0 \mathrm{~cd}$ & $3.67 \mathrm{e}$ & $12.2 \mathrm{e}$ & $51.0 \mathrm{a}$ \\
\hline & Sinal + Select super & $25.3 \mathrm{c}$ & 39.7 b & $26.6 \mathrm{~cd}$ & $34.2 \mathrm{~cd}$ & $49.3 \mathrm{bc}$ \\
\hline & Hand weeding & $8.25 \mathrm{~d}$ & $34.7 \mathrm{bc}$ & $19.9 \mathrm{~d}$ & $53.4 \mathrm{c}$ & $48.1 \mathrm{c}$ \\
\hline & Unweeded check & $219.6 \mathrm{~b}$ & $559.1 \mathrm{a}$ & $261.6 \mathrm{~b}$ & $515.2 \mathrm{~b}$ & $23.8 \mathrm{~d}$ \\
\hline
\end{tabular}


TABLE 5. Means for fertilization * weed control treatments interaction effects on fresh weight $\left(\mathrm{g} / \mathrm{m}^{2}\right)$ of weed categories in the two seasons.

\begin{tabular}{|c|c|c|c|c|c|c|c|}
\hline \multirow[b]{2}{*}{ Fertilization } & \multirow{2}{*}{$\begin{array}{l}\text { Weed control } \\
\text { treatments }\end{array}$} & \multicolumn{3}{|c|}{$2013 / 2014$} & \multicolumn{3}{|c|}{$2014 / 2015$} \\
\hline & & $\begin{array}{l}\text { Broad- } \\
\text { leaved } \\
\text { weeds }\end{array}$ & $\begin{array}{l}\text { Grass } \\
\text { weeds }\end{array}$ & $\begin{array}{c}\text { Total } \\
\text { weeds }\end{array}$ & $\begin{array}{l}\text { Broad- } \\
\text { leaved } \\
\text { weeds }\end{array}$ & $\begin{array}{l}\text { Grass } \\
\text { weeds }\end{array}$ & $\begin{array}{r}\text { Total } \\
\text { weeds }\end{array}$ \\
\hline N P K & $\begin{array}{l}\text { Brominal+Select } \\
\text { super } \\
\text { Sinal+Select super } \\
\text { Hand hoeing } \\
\text { Unweeded check }\end{array}$ & $\begin{array}{c}5.25 \mathrm{~d} \\
36.2 \mathrm{c} \\
5.12 \mathrm{~d} \\
275.7 \mathrm{a}\end{array}$ & $\begin{array}{c}5.75 \mathrm{~cd} \\
3.62 \mathrm{~d} \\
29.6 \mathrm{c} \\
283.4 \mathrm{a}\end{array}$ & $\begin{array}{c}11.0 \mathrm{de} \\
39.7 \mathrm{~d} \\
34.7 \mathrm{de} \\
559.1 \mathrm{a}\end{array}$ & $\begin{array}{c}5.50 \mathrm{f} \\
35.4 \mathrm{~d} \\
16.1 \mathrm{def} \\
329.5 \mathrm{a}\end{array}$ & $\begin{array}{c}7.75 \mathrm{f} \\
7.87 \mathrm{f} \\
35.9 \mathrm{~d} \\
317.6 \mathrm{a}\end{array}$ & $\begin{array}{c}13.2 \mathrm{f} \\
43.2 \mathrm{de} \\
52.0 \mathrm{~d} \\
647.1 \mathrm{a}\end{array}$ \\
\hline NP & $\begin{array}{l}\text { Brominal+Select } \\
\text { super } \\
\text { Sinal+Select super } \\
\text { Hand hoeing } \\
\text { Unweeded check }\end{array}$ & $\begin{array}{c}5.75 \mathrm{~d} \\
34.1 \mathrm{c} \\
5.62 \mathrm{~d} \\
262.4 \mathrm{a}\end{array}$ & $\begin{array}{l}2.75 \mathrm{~d} \\
6.12 \mathrm{~cd} \\
25.0 \mathrm{~cd} \\
262.2 \mathrm{a}\end{array}$ & $\begin{array}{c}8.50 \mathrm{e} \\
40.5 \mathrm{~d} \\
30.6 \mathrm{de} \\
524.6 \mathrm{~b}\end{array}$ & $\begin{array}{c}8.50 \mathrm{ef} \\
33.4 \mathrm{~d} \\
16.4 \mathrm{def} \\
296.6 \mathrm{~b}\end{array}$ & $\begin{array}{l}12.0 \mathrm{ef} \\
12.5 \mathrm{ef} \\
28.6 \mathrm{de} \\
284.0 \mathrm{~b}\end{array}$ & $\begin{array}{l}20.5 \mathrm{ef} \\
45.9 \mathrm{de} \\
45.0 \mathrm{de} \\
580.6 \mathrm{~b}\end{array}$ \\
\hline $\mathrm{P}$ & $\begin{array}{l}\text { Brominal+Select } \\
\text { super } \\
\text { Sinal+Select super } \\
\text { Hand hoeing } \\
\text { Unweeded check }\end{array}$ & $\begin{array}{c}4.50 \mathrm{~d} \\
27.4 \mathrm{c} \\
11.6 \mathrm{~cd} \\
228.7 \mathrm{~b}\end{array}$ & $\begin{array}{c}4.25 \mathrm{~d} \\
4.12 \mathrm{~d} \\
27.0 \mathrm{~cd} \\
204.4 \mathrm{~b}\end{array}$ & $\begin{array}{c}8.75 \mathrm{e} \\
31.5 \mathrm{de} \\
38.6 \mathrm{~d} \\
433.1 \mathrm{c}\end{array}$ & $\begin{array}{l}7.87 \mathrm{ef} \\
27.5 \mathrm{de} \\
25.1 \mathrm{def} \\
259.1 \mathrm{c}\end{array}$ & $\begin{array}{c}8.75 \mathrm{f} \\
13.7 \mathrm{ef} \\
36.7 \mathrm{~d} \\
225.5 \mathrm{c}\end{array}$ & $\begin{array}{c}16.6 \mathrm{f} \\
41.2 \mathrm{de} \\
61.9 \mathrm{~d} \\
484.6 \mathrm{c}\end{array}$ \\
\hline
\end{tabular}

In the second season, Brominal + Select super was superior than Sinal + Select super at NPK and P treatments, whereas both herbicide combinations were statistically similar at NP macronutrient fertilization treatment. These variations in weeds response to fertilization treatments and post-emergence herbicides application emphasize the need for adopting suitable macronutrients fertilization program, including amounts and time of application, that would reduce competition of weeds with flax crop plants for those nutrients and in parallel association, application of effective postemergence herbicides combination targeted to reduce weeds density at the critical growth stages of flax.

Effect of tillage, fertilization and weed control treatments and their interactions on phenologic, yield and yield components of flax

No-tillage (NT) gave comparable values to that of conventional tillage (CT) for all studied characters (Tables 6 and 7), in the two seasons, except number of fruiting branches and straw yield/ha in the first season, and plant height in the second season. NT gave significant higher number of fruiting branches but lower straw yield compared to CT. Meanwhile, flax plants, in the second season were taller with CT system compared to NT system. These findings were in accordance with those reported by Couture et al. (2004) who found that zero tillage (ZT) produced shorter plants compared to minimum (RT) or conventional tillage (CT) and attributed to better seed bed preparation and seed placement in RT and CT compared to ZT. Foulk et al. (2007) reported that CT produced dry plant matter yield compared to NT. The results also indicated the seed yield in NT system statistically matched than CT system, in the two seasons, in addition to other important yield components such as number of capsules per plant and 1000-seed weight (for oil production) and technical length (for fiber production). Similar findings were reported by Mankowski \& Pudelko (2015) and Pittelkow et al. (2015).

NPK and NP fertilization increased the seed yield by 57.1 and $51.4 \%$ and 69.1 and $50.7 \%$, in the two seasons, respectively compared to $\mathrm{P}$ fertilization treatments (Tables 6 and 7). Fertilization with the three macronutrients (NPK) was significantly superior to $\mathrm{P}$ application only in all studied characters in the two seasons, except technical length and number of fruiting and basal branches in the first season. It was also significantly superior to NP application in seed and straw yields and 1000-seed weight in the two seasons that indicated the necessity of balanced fertilization with the three macronutrients to 
obtain high economic seed yield of flax. These findings are supported by those reported by Leilah et al. (2003), Dordas (2010), Khajani et al. (2012) and Bakry et al. (2015), who found that adequate supply of nitrogen, phosphorus and potassium enhanced both seed and fiber production of flax. Concerning weed control treatments, data reported in Tables 6 and 7 showed that applied herbicide combinations and hand weeding significantly improved all studied characters, in the two seasons, compared to unweeded check. Percent increase in seed yield, over control, was 71,69 and $68.5 \%$ and $68,67.5$ and $68.4 \%$, for the two seasons, respectively.

Moreover, Brominal + Select super postemergent herbicide combination surpassed hand weeding in number of capsules per plant in the two seasons, and plant height, number of fruiting branches, length of fruiting zone, straw yield and seed yield in the second season. However, both herbicide combinations gave statistically similar values for all studied traits, in the two seasons, except number of capsules per plant in the first season, where Brominal + Select super significantly surpassed Sinal + Select super. These findings support the adoption of a postemergence-herbicide-application program that will reduce weeds development and growth, reducing its competition with flax plants and ensure higher seed and fiber production. Similar findings were reported by Osman et al. (2010), Thomas et al. (2010) and Mankowski \& Pudelko (2015), who emphasized the efficacy of different weed control methods, including post-emergence herbicides, in suppressing weeds density and growth to provide the crop plants with suitable environment to realize their potential productivity.

Tillage system $\mathrm{x}$ weed control treatments interaction was significant for number of capsules per plant in the first season only (Table 7). Both herbicidal combinations gave comparable values under CT and NT systems and were significantly superior to unweeded control. However, hand weeding at CT gave higher number of capsules per plant than at NT. On the contrary, unweeded control at NT gave significantly higher number of capsules per plant compared to that under CT. That may be attributed to the lower density of weeds in NT, compared to CT (Table 4), which resulted in better growth of flax plants and formation of higher number of capsules. These results were in accordance with those reported by Mankowski et al. (2013) who found that notillage, regardless of weed control, reduced the number and weight of weeds compared to conventional tillage.

TABLE 6. Means for phenologic, yield and yield components characters as influenced by tillage system, fertilization and weed control treatments in 2013/2014.

\begin{tabular}{|c|c|c|c|c|c|c|c|c|c|c|c|}
\hline Treatments & & $\begin{array}{l}\text { Plant } \\
\text { height } \\
\text { (cm) }\end{array}$ & $\begin{array}{l}\text { Technical } \\
\text { length } \\
(\mathbf{c m})\end{array}$ & $\begin{array}{c}\text { No. of } \\
\text { capsules / } \\
\text { plant }\end{array}$ & $\begin{array}{c}\text { No. of apical } \\
\text { branches/ } \\
\text { plant }\end{array}$ & $\begin{array}{c}\text { No. of basal } \\
\text { branches/ } \\
\text { plant }\end{array}$ & $\begin{array}{l}\text { Fruit- } \\
\text { ing zone } \\
\text { length } \\
\text { (cm) }\end{array}$ & $\begin{array}{c}\text { Straw } \\
\text { yield } \\
\text { (kg/ } \\
\text { ha) }\end{array}$ & $\begin{array}{c}\text { Seed } \\
\text { yield } \\
\text { (kg/ } \\
\text { ha) }\end{array}$ & $\begin{array}{l}\text { Harvest } \\
\text { index }\end{array}$ & $\begin{array}{c}1000 \\
\text { seed } \\
\text { weight } \\
(\mathrm{g})\end{array}$ \\
\hline \multicolumn{12}{|l|}{ Tillage(T): } \\
\hline- & Conventional tillage (CT) & $94.6 \mathrm{a}$ & $63.8 \mathrm{a}$ & $37.9 \mathrm{a}$ & $29.7 b$ & $3.69 \mathrm{a}$ & $38.5 \mathrm{a}$ & $4435.8 \mathrm{a}$ & $1562.0 \mathrm{a}$ & $34.1 \mathrm{a}$ & $6.78 \mathrm{a}$ \\
\hline- & No tillage (NT) & $96.4 \mathrm{a}$ & $63.5 \mathrm{a}$ & $39.9 \mathrm{a}$ & $31.9 \mathrm{a}$ & 3.94 a & $36.8 \mathrm{a}$ & $3946.8 b$ & $1363.7 \mathrm{a}$ & $33.2 \mathrm{a}$ & $6.69 \mathrm{a}$ \\
\hline \multicolumn{12}{|c|}{ Fertilization (F): } \\
\hline- & NPK & $100.6 \mathrm{a}$ & $64.7 \mathrm{a}$ & $45.5 \mathrm{a}$ & $34.1 \mathrm{a}$ & $3.91 \mathrm{a}$ & $39.9 \mathrm{a}$ & $4998.9 \mathrm{a}$ & $1899.7 \mathrm{a}$ & $37.8 \mathrm{a}$ & $7.60 \mathrm{a}$ \\
\hline- & $\mathrm{NP}$ & $94.9 b$ & $63.2 \mathrm{a}$ & $36.5 b$ & $29.8 \mathrm{a}$ & $3.75 \mathrm{a}$ & $37.4 b$ & $4320.6 \mathrm{~b}$ & $1674.8 \mathrm{~b}$ & $37.8 \mathrm{a}$ & $6.84 b$ \\
\hline - & $\mathrm{P}$ & $91.1 b$ & $63.1 \mathrm{a}$ & $34.7 b$ & $28.5 \mathrm{a}$ & $3.78 \mathrm{a}$ & $35.2 b$ & $3254.4 \mathrm{c}$ & $814.2 \mathrm{c}$ & $25.3 \mathrm{~b}$ & $5.76 c$ \\
\hline \multicolumn{12}{|c|}{ Weed control treatments $(W)$ : } \\
\hline- & Brominal+Select super & $103.5 \mathrm{a}$ & $67.6 \mathrm{a}$ & $48.6 \mathrm{a}$ & 36.7 a & $4.17 \mathrm{a}$ & $43.0 \mathrm{a}$ & $5194.3 \mathrm{a}$ & $1865.0 \mathrm{a}$ & $35.1 \mathrm{a}$ & $7.19 a$ \\
\hline- & Sinal-Select super & $100.2 \mathrm{a}$ & $68.0 \mathrm{a}$ & $42.9 b$ & $35.2 a b$ & $4.25 \mathrm{a}$ & 42.1ab & $4894.7 \mathrm{ab}$ & 1736.4ab & $35.1 \mathrm{a}$ & 7.31 a \\
\hline- & Hand hoeing & $96.6 b$ & $67.6 \mathrm{a}$ & $40.1 \mathrm{~b}$ & $32.8 b$ & $4.00 \mathrm{a}$ & $41.2 b$ & $4855.9 \mathrm{~b}$ & $1711.7 \mathrm{~b}$ & $34.5 \mathrm{a}$ & $7.25 \mathrm{a}$ \\
\hline - & Unweeded check & $81.7 \mathrm{c}$ & $51.4 b$ & $23.9 \mathrm{c}$ & $18.4 \mathrm{c}$ & $2.83 \mathrm{~b}$ & $23.6 \mathrm{c}$ & $1820.2 \mathrm{c}$ & $538.6 \mathrm{c}$ & $29.9 \mathrm{~b}$ & $5.19 b$ \\
\hline \multicolumn{12}{|l|}{ Interactions: } \\
\hline- & $T * F$ & ** & ns & ns & ns & ns & ns & ns & ns & ns & ns \\
\hline - & $T * W$ & ns & ns & ns & ns & ns & ns & ns & ns & ns & ns \\
\hline - & $F^{*} W$ & ns & ns & ns & ns & ns & ns & $*$ & $* *$ & ns & $* *$ \\
\hline - & $\mathrm{T} * \mathrm{~F} * \mathrm{~W}$ & ns & ns & ns & ns & ns & ns & ns & ns & ns & ns \\
\hline
\end{tabular}


TABLE 7. Means for phenologic, yield and yield components characters as influenced by tillage system, fertilization and weed control treatments in 2014/2015

\begin{tabular}{|c|c|c|c|c|c|c|c|c|c|c|}
\hline Treatments & $\begin{array}{c}\text { Plant } \\
\text { height } \\
(\mathrm{cm})\end{array}$ & $\begin{array}{c}\text { Technical } \\
\text { length } \\
(\mathrm{cm})\end{array}$ & $\begin{array}{c}\text { No. of } \\
\text { capsules/ } \\
\text { plant }\end{array}$ & $\begin{array}{c}\text { No. of } \\
\text { apical } \\
\text { branches/ } \\
\text { plant }\end{array}$ & $\begin{array}{c}\text { No. of } \\
\text { basal } \\
\text { branches/ } \\
\text { plant }\end{array}$ & $\begin{array}{l}\text { Fruiting } \\
\text { zone length } \\
\text { (cm) }\end{array}$ & $\begin{array}{c}\text { Straw } \\
\text { yield (kg/ } \\
\text { ha) }\end{array}$ & $\begin{array}{c}\text { Seed } \\
\text { yield } \\
\text { (kg/ha) }\end{array}$ & $\begin{array}{c}\text { Harvest } \\
\text { index }\end{array}$ & $\begin{array}{l}1000 \text { seed } \\
\text { weight (g) }\end{array}$ \\
\hline \multicolumn{11}{|l|}{ Tillage (T): } \\
\hline - Conventional tillage (CT) & $97.8 \mathrm{a}$ & $62.5 \mathrm{a}$ & $42.9 \mathrm{a}$ & $31.6 \mathrm{a}$ & $3.75 \mathrm{a}$ & $37.6 \mathrm{a}$ & $4365.6 \mathrm{a}$ & $1530.1 \mathrm{a}$ & $33.5 \mathrm{a}$ & $6.59 \mathrm{a}$ \\
\hline - No tillage (NT) & $95.0 \mathrm{~b}$ & $61.6 \mathrm{a}$ & $43.1 \mathrm{a}$ & $31.6 \mathrm{a}$ & $3.92 \mathrm{a}$ & $36.9 \mathrm{a}$ & 4170.7 a & $1464.2 \mathrm{a}$ & $33.3 \mathrm{a}$ & $6.41 \mathrm{a}$ \\
\hline \multicolumn{11}{|l|}{ Fertilization $(\mathrm{F})$ : } \\
\hline NPK & $103.7 \mathrm{a}$ & $65.2 \mathrm{a}$ & $50.6 \mathrm{a}$ & $36.1 \mathrm{a}$ & $4.03 \mathrm{a}$ & $41.1 \mathrm{a}$ & $5432.6 \mathrm{a}$ & $2034.4 \mathrm{a}$ & $37.1 \mathrm{a}$ & $7.81 \mathrm{a}$ \\
\hline NP & $94.1 \mathrm{~b}$ & $61.4 \mathrm{~b}$ & $43.1 \mathrm{~b}$ & $32.5 b$ & $3.84 \mathrm{ab}$ & $37.6 \mathrm{~b}$ & $4396.3 b$ & $1646.0 \mathrm{~b}$ & $36.5 \mathrm{a}$ & $6.47 \mathrm{~b}$ \\
\hline $\mathrm{P}$ & $91.5 \mathrm{~b}$ & $59.7 \mathrm{~b}$ & $35.3 \mathrm{c}$ & $26.3 \mathrm{c}$ & $3.62 \mathrm{~b}$ & $33.0 \mathrm{c}$ & $2975.5 \mathrm{c}$ & $810.9 \mathrm{c}$ & $26.6 b$ & $5.22 \mathrm{c}$ \\
\hline \multicolumn{11}{|l|}{ Weed control treatments (W): } \\
\hline - Brominal+Select super & $103.6 \mathrm{a}$ & $65.9 \mathrm{a}$ & $51.5 \mathrm{a}$ & $36.6 \mathrm{a}$ & $4.29 a$ & $42.0 \mathrm{a}$ & $5063.7 \mathrm{a}$ & $1805.9 \mathrm{a}$ & $34.8 \mathrm{a}$ & $7.12 \mathrm{a}$ \\
\hline - Sinal+Select super & $100.9 \mathrm{a}$ & $65.5 \mathrm{a}$ & $49.2 \mathrm{~b}$ & $35.9 \mathrm{a}$ & $4.33 \mathrm{a}$ & $41.2 \mathrm{a}$ & $4967.8 \mathrm{a}$ & $1776.9 \mathrm{a}$ & $34.9 \mathrm{a}$ & $7.00 \mathrm{a}$ \\
\hline - Hand hoeing & $100.5 \mathrm{a}$ & $66.2 \mathrm{a}$ & $49.0 \mathrm{~b}$ & $36.4 \mathrm{a}$ & $4.17 \mathrm{a}$ & $42.1 \mathrm{a}$ & $5034.9 \mathrm{a}$ & $1828.1 \mathrm{a}$ & $35.5 \mathrm{a}$ & $7.15 \mathrm{a}$ \\
\hline - Unweeded check & $80.7 \mathrm{~b}$ & $50.8 \mathrm{~b}$ & $22.2 \mathrm{c}$ & $17.6 \mathrm{~b}$ & $2.54 \mathrm{~b}$ & $23.7 b$ & $2006.1 \mathrm{~b}$ & $577.6 \mathrm{~b}$ & $28.4 b$ & $4.73 b$ \\
\hline
\end{tabular}

\begin{tabular}{ll}
\multicolumn{2}{l}{ Interactions: } \\
- & $\mathrm{T} * \mathrm{~F}$ \\
- & $\mathrm{T} * \mathrm{~W}$ \\
- & $\mathrm{F} * \mathrm{~W}$ \\
- & $\mathrm{T} * \mathrm{~F} * \mathrm{~W}$
\end{tabular}

$\begin{array}{llll}\mathrm{ns} & \mathrm{ns} & \mathrm{ns} & \mathrm{ns} \\ \mathrm{ns} & \mathrm{ns} & * * & \mathrm{~ns} \\ \mathrm{~ns} & \mathrm{~ns} & * * & \mathrm{~ns} \\ \mathrm{~ns} & \mathrm{~ns} & \mathrm{~ns} & \mathrm{~ns}\end{array}$

$\begin{array}{ll}\text { ns } & \text { ns } \\ \text { ns } & \text { ns } \\ \text { ns } & * * \\ \text { ns } & \text { ns }\end{array}$

$\begin{array}{llll}\mathrm{ns} & \mathrm{ns} & \mathrm{ns} & \mathrm{ns} \\ \mathrm{ns} & \mathrm{ns} & \mathrm{ns} & \mathrm{ns} \\ * * & * * & \mathrm{~ns} & * * \\ \mathrm{~ns} & \mathrm{~ns} & \mathrm{~ns} & \mathrm{~ns}\end{array}$

The tillage system $\mathrm{x}$ fertilization treatment interaction (Table 8) was significant in 2013/2014 season only. Plant height varied significantly under $\mathrm{CT}$ conditions with the different macronutrients fertilization treatments, whereas plant height was insignificantly affected by the different applied macronutrients fertilization treatments under NT system. That may be attributed to the impact of no-tillage impact on the distribution of the plant nutrients in the soil profile and their availability to plants (Grant et al., 2008).

Fertilization treatment $\mathrm{x}$ weed control treatments interaction was significant for straw yield, seed yield and 1000-seed weight in the two seasons, in addition to number of capsules per plant and length of fruiting zone in the second season (Table 9). The data revealed that the highest values were obtained with NPK followed by NP then P macronutrients fertilization for the applied weed control treatments. However, there was a variation of the magnitude effect for the three macronutrients fertilization treatments. This appeared in seed yield reduction the percent reduction in seed yield, as an average of the two seasons, for weed control treatments (the two post-emergence herbicide combinations and hand weeding) were $14 \%$ for NP compared to NPK and $52 \%$ for NP compared to P. The respective values for reduction in straw yield were $15.5 \%$ and $29 \%$, respectively. These findings illustrate the major role played by balanced macronutrients fertilization, especially nitrogen, in realizing the potential yield of flax. The data also indicate the minor role of phosphorus in maintaining high seed and straw yields of flax even under suppressed weeds conditions. Several researchers emphasized the role of balanced fertilization in flax (Franzen, 2004 and Khajani et al., 2012), whereas others accentuated the role of nitrogen and the necessity of increasing nitrogen use efficiency in flax (Dordas, 2010; El-Nagdy et al., 2010 and Ruisi et al., 2016) in order to obtain economical yield under CT or NT systems. On the other hand, several researchers pointed out the lack of response to $\mathrm{P}$ application in flax, especially in soils with high P levels (Lafond et al., 2003 and Grant et al., 2008). 
TABLE 8. Means for tillage system * fertilization interaction effects on plant height in the first season.

\begin{tabular}{lcc}
\hline Tillage & Fertilization & Plant height (cm) \\
\hline \multirow{3}{*}{ Conventional tillage (CT) } & NPK & $103.81 \mathrm{a}$ \\
& NP & $92.56 \mathrm{bc}$ \\
& $\mathrm{P}$ & $87.37 \mathrm{c}$ \\
No tillage (NT) & NPK & $97.31 \mathrm{~b}$ \\
& NP & $97.19 \mathrm{~b}$ \\
& P & $94.81 \mathrm{~b}$ \\
\hline
\end{tabular}

TABLE 9. Means for fertilization * weed control treatments interaction effects on seed yield, straw yield, 1000seed weight, number of capsules and length of fruiting zone in the two seasons.

\begin{tabular}{|c|c|c|c|c|c|c|c|c|c|}
\hline Fertilization & $\begin{array}{l}\text { Weed control } \\
\text { treatments }\end{array}$ & $\begin{array}{c}\text { Straw } \\
\text { yield } \\
\text { (kg/ha) }\end{array}$ & $\begin{array}{c}\text { Seed yield } \\
\text { (kg/ha) }\end{array}$ & $\begin{array}{c}1000 \\
\text { seed } \\
\text { weight } \\
\text { (g) }\end{array}$ & $\begin{array}{c}\text { No. of } \\
\text { capsules/ } \\
\text { plant }\end{array}$ & $\begin{array}{c}\text { No. of } \\
\text { apical } \\
\text { branches/ } \\
\text { plant }\end{array}$ & $\begin{array}{c}\text { Straw } \\
\text { yield } \\
\text { (kg/ha) }\end{array}$ & $\begin{array}{c}\text { Seed } \\
\text { yield } \\
\text { (kg/ha) }\end{array}$ & $\begin{array}{c}1000 \\
\text { seed } \\
\text { weight } \\
(\mathrm{g})\end{array}$ \\
\hline \multirow{3}{*}{ NPK } & Sinal+Select super & $5673.2 \mathrm{a}$ & $2292.4 \mathrm{a}$ & $8.25 \mathrm{a}$ & $59.12 \mathrm{a}$ & $43.57 \mathrm{ab}$ & $6328.4 \mathrm{a}$ & $2400.7 \mathrm{a}$ & $8.58 \mathrm{a}$ \\
\hline & Hand hoeing & $5905.3 \mathrm{a}$ & $2236.5 \mathrm{a}$ & $8.32 \mathrm{a}$ & $57.75 \mathrm{a}$ & $44.60 \mathrm{a}$ & $6311.8 \mathrm{a}$ & $2431.2 \mathrm{a}$ & $8.71 \mathrm{a}$ \\
\hline & Unweeded check & $2241.2 \mathrm{e}$ & $696.6 \mathrm{~d}$ & $5.55 \mathrm{~d}$ & $25.72 \mathrm{f}$ & $31.52 \mathrm{e}$ & $2656.1 \mathrm{~d}$ & $869.9 \mathrm{~d}$ & $5.21 \mathrm{c}$ \\
\hline \multirow{2}{*}{$\mathrm{PK}$} & Brominal+Select super & $5241.2 \mathrm{~b}$ & $2207.9 \mathrm{a}$ & $7.43 b$ & $52.00 \mathrm{~b}$ & $42.52 \mathrm{bc}$ & $5233.6 \mathrm{~b}$ & $1997.3 \mathrm{~b}$ & $7.08 \mathrm{~b}$ \\
\hline & Sinal+Select super & $5093.2 \mathrm{~b}$ & $1992.5 \mathrm{~b}$ & $7.60 \mathrm{~b}$ & $48.67 \mathrm{c}$ & $42.15 \mathrm{c}$ & $5164.6 \mathrm{~b}$ & $1979.4 \mathrm{~b}$ & $7.00 \mathrm{~b}$ \\
\hline \multirow{4}{*}{$\mathrm{K}$} & Brominal+Select super & $4166.2 \mathrm{c}$ & $1013.9 \mathrm{c}$ & $5.83 \mathrm{c}$ & $42.70 \mathrm{~d}$ & $38.87 \mathrm{~d}$ & $3520.0 \mathrm{c}$ & $984.6 \mathrm{c}$ & $5.53 \mathrm{c}$ \\
\hline & Sinal+Select super & $3917.5 \mathrm{~cd}$ & $923.9 \mathrm{c}$ & $6.09 \mathrm{c}$ & $39.95 \mathrm{e}$ & $37.75 \mathrm{~d}$ & $3410.5 \mathrm{c}$ & $950.1 \mathrm{c}$ & $5.42 \mathrm{c}$ \\
\hline & Hand hoeing & $3524.8 \mathrm{~d}$ & $953.7 \mathrm{c}$ & $6.01 \mathrm{c}$ & $40.42 \mathrm{e}$ & $38.45 \mathrm{~d}$ & $3555.7 \mathrm{c}$ & $1007.2 \mathrm{c}$ & $5.52 \mathrm{c}$ \\
\hline & Unweeded check & $1409.2 \mathrm{f}$ & $365.3 \mathrm{e}$ & $5.10 \mathrm{e}$ & $18.22 \mathrm{~h}$ & $17.12 \mathrm{~g}$ & $1413.7 \mathrm{f}$ & $301.5 \mathrm{f}$ & $4.41 \mathrm{~d}$ \\
\hline
\end{tabular}

Effect of tillage, fertilization and weed control treatments and their interactions on profitability of flax crop

Data in Table 10 indicated that tillage $(\mathrm{T})$ significantly increased gross income, net income, profitability and Benefit/Costs ratio $(\mathrm{B} / \mathrm{C})$ by 13.7 , $23.1,21.7$ and $22.2 \%$ in the first season and by $11.5,20.2,20.7$ and $12.2 \%$ in the second season, respectively, as compared with no-tillage (NT).

Fertilization with the three macronutrients (NPK) was significantly superior than NP and P application only in all economic studied characters (Table 10). As well as NP was significantly superior than $\mathrm{P}$ application in all economic studied characters during the two seasons. That indicated the necessity of balanced fertilization with the three macronutrients to obtain high economic seed yield of flax.

Concerning weed control treatments, data reported in Tables 10 showed that applied herbicide combinations and hand weeding significantly increased all economic studied characters, in the two seasons, compared to unweeded control. Moreover, both herbicidal combinations surpassed hand weeding in net income, profitability and benefit/costs ratio (b/c) during the two seasons. However, both herbicide combinations gave statistically similar values for all studied traitsexcept gross income.

Tillage systems $\mathrm{x}$ weed control treatments interaction was significant for gross income, net income, profitability and benefit/costs ratio $(\mathrm{b} / \mathrm{c})$ in Table 11. The data revealed that the highest values were obtained from applied both herbicide combinations and hand weeding with both tillage systems compared to unweeded control. On the other hand, there was no variation among both herbicide combinations and hand weeding in gross income, however, both herbicide combinations surpassed to hand weeding in net income, profitability and benefit/ costs ratio during the two seasons. 
TABLE 10. Effect of tillage system, fertilization and weed control treatments on profitability of flax crop in the two seasons.

\begin{tabular}{|c|c|c|c|c|c|c|c|c|}
\hline \multirow[b]{2}{*}{ Treatments } & \multicolumn{4}{|c|}{ 2013/2014 } & \multicolumn{4}{|c|}{ 2014/2015 } \\
\hline & Gross & $\begin{array}{c}\text { Net } \\
\text { income } \\
\text { LE }\end{array}$ & Profitability & $\begin{array}{c}\text { Benefit/ } \\
\text { Costs } \\
\text { ratio } \\
(\mathrm{B} / \mathrm{C}) \\
\end{array}$ & $\begin{array}{c}\text { Gross } \\
\text { income } \\
\text { LE }\end{array}$ & $\begin{array}{c}\text { Net } \\
\text { income } \\
\text { LE }\end{array}$ & Profitability & $\begin{array}{c}\text { Benefit/ } \\
\text { Costs } \\
\text { ratio } \\
(\mathrm{B} / \mathrm{C}) \\
\end{array}$ \\
\hline \multicolumn{9}{|l|}{ Tillage: } \\
\hline - Conventional tillage (CT) & $5332 \mathrm{a}$ & $2362 \mathrm{a}$ & $0.756 \mathrm{a}$ & $1.76 \mathrm{a}$ & $6747 \mathrm{a}$ & $3183 \mathrm{a}$ & $0.838 \mathrm{a}$ & $1.84 \mathrm{a}$ \\
\hline - No tillage (NT) & $4689 \mathrm{~b}$ & $1919 \mathrm{~b}$ & $0.621 \mathrm{~b}$ & $1.44 \mathrm{~b}$ & $6052 \mathrm{~b}$ & $2648 \mathrm{~b}$ & $0.694 \mathrm{~b}$ & $1.64 \mathrm{~b}$ \\
\hline \multicolumn{9}{|l|}{ Fertilization: } \\
\hline - NPK & $6301 \mathrm{a}$ & $2881 \mathrm{a}$ & $0.834 \mathrm{a}$ & $1.83 \mathrm{a}$ & 8752 a & $4648 \mathrm{a}$ & $1.123 \mathrm{a}$ & $2.12 \mathrm{a}$ \\
\hline$-\quad N P$ & $5516 \mathrm{~b}$ & $2346 \mathrm{~b}$ & $0.733 \mathrm{~b}$ & $1.73 \mathrm{~b}$ & $7081 \mathrm{~b}$ & $3277 \mathrm{~b}$ & $0.848 \mathrm{~b}$ & $1.85 \mathrm{~b}$ \\
\hline$-\quad P$ & $3215 \mathrm{c}$ & $595 \mathrm{c}$ & $0.228 \mathrm{c}$ & $1.23 \mathrm{c}$ & $3965 \mathrm{c}$ & $821 \mathrm{c}$ & $0.253 \mathrm{c}$ & $1.25 \mathrm{c}$ \\
\hline \multicolumn{9}{|l|}{ Weed control treatments: } \\
\hline - Prominal+Select super & $6319 \mathrm{a}$ & 3339 a & $1.090 \mathrm{a}$ & $2.09 \mathrm{a}$ & $7911 \mathrm{a}$ & $4335 \mathrm{a}$ & $1.165 \mathrm{a}$ & $2.16 \mathrm{a}$ \\
\hline - Sinal+Select super & $5910 \mathrm{a}$ & $2940 \mathrm{a}$ & $0.960 \mathrm{a}$ & $1.96 \mathrm{a}$ & $7775 \mathrm{a}$ & $4211 \mathrm{a}$ & $1.136 \mathrm{a}$ & $2.14 \mathrm{a}$ \\
\hline - and hoeing & 5841 a & $2376 \mathrm{~b}$ & $0.660 \mathrm{~b}$ & $1.66 \mathrm{~b}$ & $7954 \mathrm{a}$ & $3796 \mathrm{~b}$ & $0.876 \mathrm{~b}$ & $1.88 \mathrm{~b}$ \\
\hline - Unweeded check & $1973 \mathrm{c}$ & $-892 \mathrm{c}$ & $-0.317 \mathrm{c}$ & $0.68 \mathrm{c}$ & $2757 \mathrm{~b}$ & $-680 c$ & $-0.214 c$ & $0.79 \mathrm{c}$ \\
\hline \multicolumn{9}{|l|}{ Interactions: } \\
\hline$-\quad \mathrm{T} * \mathrm{~F}$ & NS & NS & NS & NS & NS & NS & NS & NS \\
\hline - $\quad \mathrm{T} * \mathrm{~W}$ & $* *$ & $* *$ & ** & $* *$ & ** & ** & ** & ** \\
\hline$-\quad F * W$ & ** & ** & ** & ** & ** & ** & $* *$ & ** \\
\hline - $\quad \mathrm{T} * \mathrm{~F} * \mathrm{~W}$ & NS & NS & NS & NS & NS & NS & NS & NS \\
\hline
\end{tabular}

TABLE 11. Means for tillage system * weed control treatment interaction effects on profitability of flax crop in the two seasons.

\begin{tabular}{|c|c|c|c|c|c|c|c|c|c|}
\hline \multirow[b]{2}{*}{ Tillage } & \multirow[b]{2}{*}{$\begin{array}{c}\text { Weed control } \\
\text { treatment }\end{array}$} & \multicolumn{4}{|c|}{$2013 / 2014$} & \multicolumn{4}{|c|}{$2014 / 2015$} \\
\hline & & $\begin{array}{c}\text { Gross } \\
\text { income } \\
\text { LE }\end{array}$ & $\begin{array}{c}\text { Net } \\
\text { income } \\
\text { LE }\end{array}$ & Profitability & $\begin{array}{c}\text { Benefit/ } \\
\text { Costs } \\
\text { ratio } \\
(\mathrm{B} / \mathrm{C})\end{array}$ & $\begin{array}{c}\text { Gross } \\
\text { income } \\
\text { LE }\end{array}$ & $\begin{array}{c}\text { Net } \\
\text { income } \\
\text { LE }\end{array}$ & Profitability & $\begin{array}{c}\text { Benefit/ } \\
\text { Costs } \\
\text { ratio } \\
(\mathrm{B} / \mathrm{C})\end{array}$ \\
\hline \multirow{4}{*}{$\begin{array}{l}\text { Conventional } \\
\text { tillage }(\mathrm{CT})\end{array}$} & Brominal+Select super & $6705 \mathrm{a}$ & $3825 \mathrm{a}$ & $1.29 \mathrm{a}$ & $2.29 \mathrm{a}$ & $8014 \mathrm{a}$ & $4558 \mathrm{a}$ & $1.27 \mathrm{a}$ & $2.27 \mathrm{a}$ \\
\hline & Sinal+Select super & $6230 \mathrm{a}$ & $3360 \mathrm{a}$ & $1.19 \mathrm{a}$ & $2.14 \mathrm{ab}$ & 7921 a & $4477 \mathrm{a}$ & $1.25 \mathrm{a}$ & $2.25 \mathrm{a}$ \\
\hline & Hand hoeing & $6226 \mathrm{a}$ & $2861 \mathrm{~b}$ & $0.98 \mathrm{ab}$ & $1.82 \mathrm{c}$ & $8028 \mathrm{a}$ & 3990 a & $0.95 \mathrm{ab}$ & $1.95 \mathrm{ab}$ \\
\hline & Unweeded check & $2167 \mathrm{~b}$ & $-598 c$ & $-0.22 c$ & $0.78 \mathrm{e}$ & $3025 \mathrm{~b}$ & $-293 b$ & $-0.11 c$ & $0.89 \mathrm{c}$ \\
\hline \multirow{4}{*}{$\begin{array}{l}\text { No tillage } \\
\text { (NT) }\end{array}$} & Brominal+Select super & 5932 a & $3252 \mathrm{a}$ & $1.03 \mathrm{ab}$ & $1.89 \mathrm{bc}$ & $7809 a$ & 4113 a & $1.07 \mathrm{ab}$ & $2.06 \mathrm{ab}$ \\
\hline & Sinal+Select super & $5591 \mathrm{a}$ & $3121 \mathrm{a}$ & $1.00 \mathrm{ab}$ & $1.78 \mathrm{bc}$ & $7629 a$ & $3945 \mathrm{a}$ & $1.02 \mathrm{ab}$ & $2.02 \mathrm{ab}$ \\
\hline & Hand hoeing & $5455 \mathrm{a}$ & $2690 \mathrm{~b}$ & $0.51 \mathrm{~b}$ & $1.51 \mathrm{~d}$ & $7880 \mathrm{a}$ & $3602 \mathrm{a}$ & $0.81 \mathrm{~b}$ & $1.81 \mathrm{~b}$ \\
\hline & Unweeded check & $1779 \mathrm{~b}$ & $-1186 c$ & $-0.41 c$ & $0.59 \mathrm{e}$ & $2490 \mathrm{~b}$ & $-1068 b$ & $-0.32 c$ & $0.68 \mathrm{c}$ \\
\hline
\end{tabular}


Fertilization $\mathrm{x}$ weed control interaction was significant for all economic studied characters in the two seasons (Table 12). The data revealed that the highest values were obtained with NPK followed by NP then P macronutrients fertilization for the applied weed control treatments. However, there was a variation in the magnitude effect for the three macronutrients fertilization treatments. The reduction percentage reduction in net income and profitability for weed control treatments (The two post-emergence herbicidal combination and hand weeding) were $18 \%$ and $6 \%$ for NP compared to NPK, $65 \%$ and $52 \%$ for P compared to NP, respectively, in the first season, however it were $27 \%$ and $18 \%$ for NP compared to NPK, $68 \%$ and $60 \%$ for $\mathrm{P}$ compared to NP, respectively, in the second season. These findings illustrate the major role played by balanced macronutrients fertilization, especially nitrogen, in realizing the potential yield of flax.

\section{Correlation between studied characters}

Simple correlation coefficients between pairs of studied characters (Tables 13 and 14), in the two seasons, revealed several important findings. First, a negative and highly significant relationship between fresh weight of either/or both groups of weeds with growth characters and seed yield and its components of flax except harvest index during the both seasons. That could be interpreted as a reduction in flax plant growth, expressed in plant height, Technical length, No. of capsules, No. of apical branches/plant, No. of basal branches/plant and Fruiting zone length, as weed population, of any of the two types of weeds increased. Second, a positive and highly significant relationship between all studied growth characters and straw yield and seed yield and its components. Increase in growth characters will lead to increase in photosynthetic production and higher dry matter accumulation which reflected in higher seed yield components and seed yield. Third, a positive and highly significant relationship between seed yield components and seed yield per fad, which implies that increase in seed yield components which related will result in higher seed yield per fed, depending on the contribution of each components in the expression of seed yield. Similar results were reported by Dordas (2010) and Thomas et al. (2010), who concluded that seed yield was positively and significantly correlated with other involved traits.

In conclusion, the present study indicated that no-tillage was equivalent to conventional tillage concerning productivity of seed from dual purpose flax. A balanced fertilization program with nitrogen, phosphorus and potassium is essential for realizing high yields in association with postemergence herbicides application to suppress weeds at critical stages of flax development. Other aspects such as reorganization of the components of crop management (Crop rotation) and organic matter management should be integrated with no-tillage to realize the full benefits of conservation agriculture.

TABLE 12.Means for fertilization * weed control treatment interaction effects on profitability of flax crop in the two seasons.

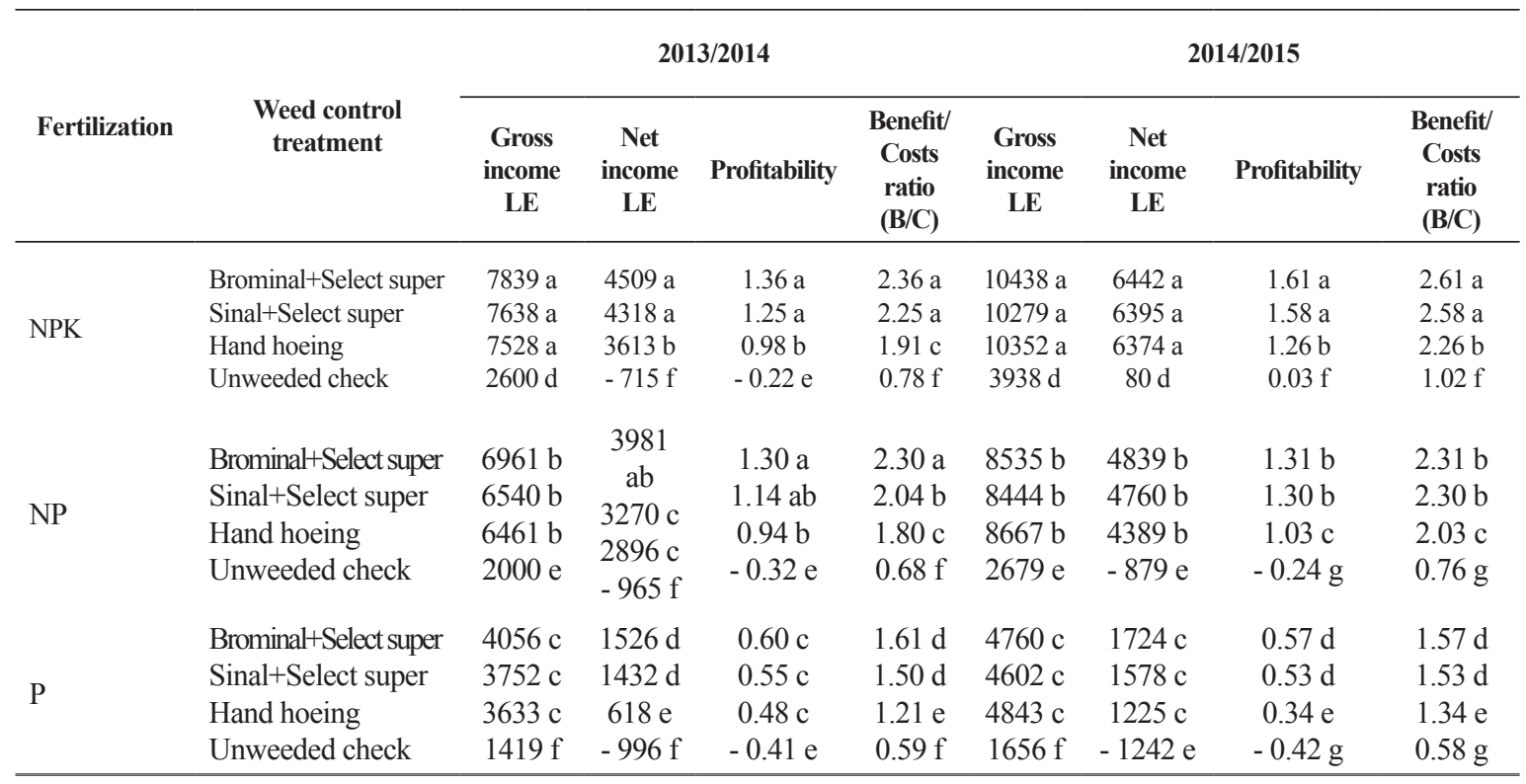




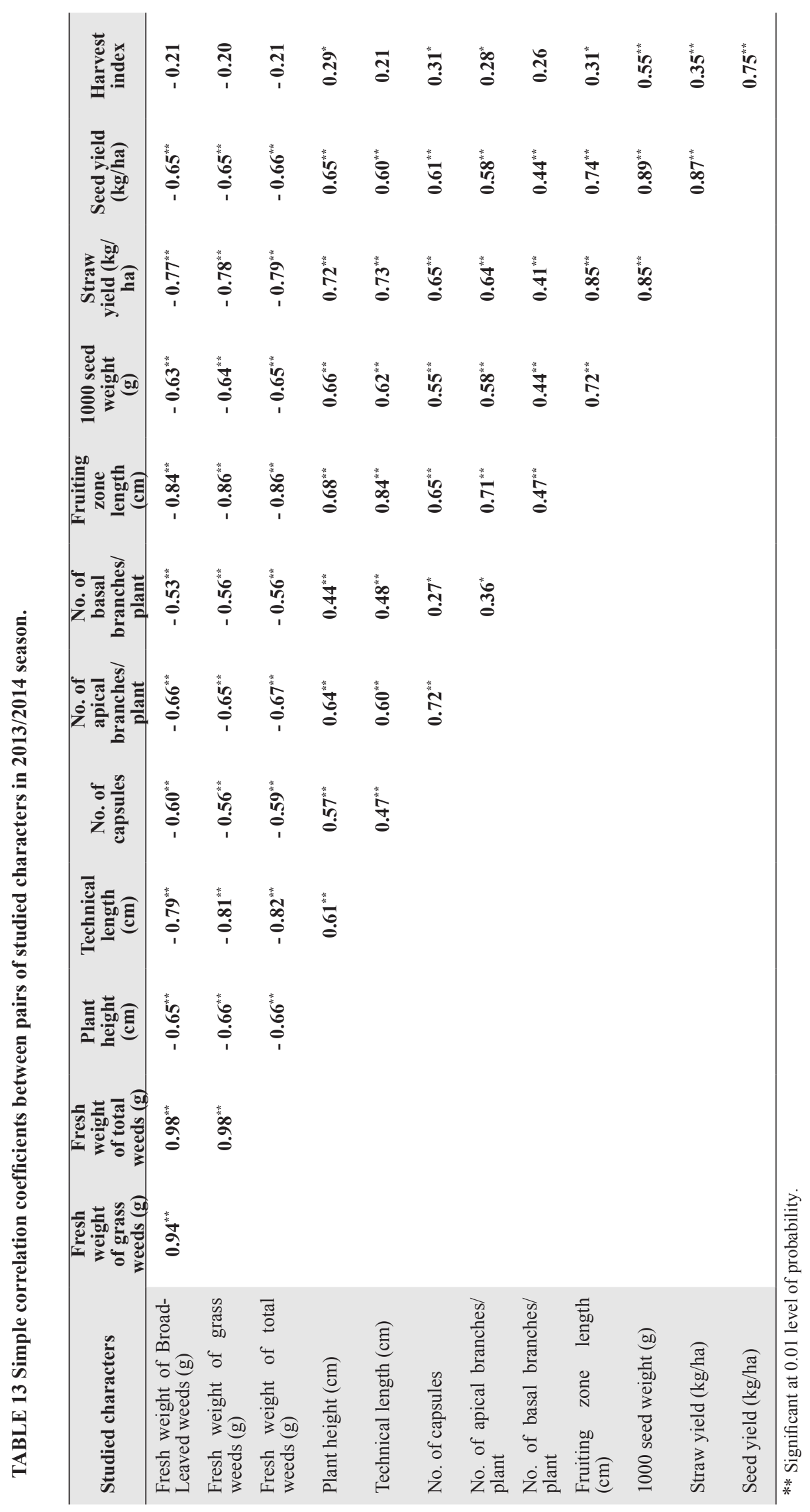

Egypt.J.Agron. Vol.39, No.2 (2017) 


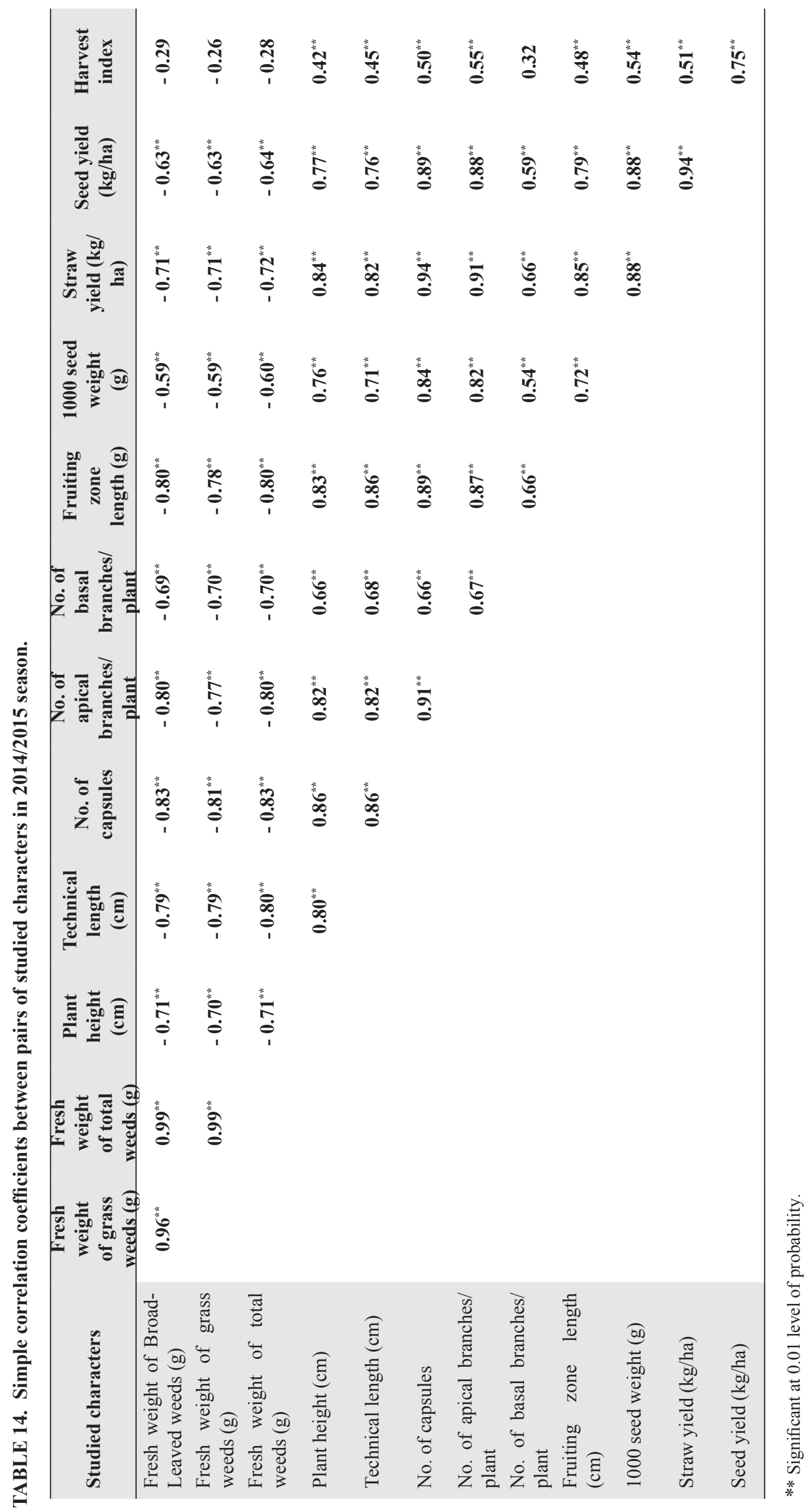

Egypt.J.Agron. Vol.39, No.2(2017) 


\section{References}

Abd El-Samie, F. S. and Abd El-Dayem, M. A. (2000) Effect of seeding patterns, tillage systems and weed control on yield and quality of flax. Fayoum J. Agric., Res. Dev. 14,175-188.

Bakry, B. A., Nofal, O. A., Zeidan, M. S. and Hozayn, M. (2015) Potassium and zinc in relation to improve flax varieties yield and yield components as grown under sandy soil conditions. Agricultural Sciences, 6, 152-158.

Blackshaw, R. E., Larney, F. J. , Lindwall, C. W., Watson, P. R. and Derksen, D. A. (2001) Tillage intensity and crop rotation affect weed community dynamics in a winter wheat cropping system. Canadian Journal of Plant Science, 81 (4), 805813.

Blackshaw, R. E., Harker, K. N. , O'Donovan, J. T., Beckie, H. J. and Smith, E. G. (2008.) Ongoing development of integrated weed management systems on the Canadian prairies. Weed Science, 56 (1),146-150

Blubaugh, C. K. and Kaplan, I. (2015) Tillage compromises weed seed predator activity across developmental stages. Boil. Control, 81, 76-82.

Couture, S. J., DiTommaso, A., Asbil, W. L. and Watson, A. K. (2004) Evaluation of fiber flax (Linum usitatissimum L.) performance under minimal and zero tillage in eastern Canada. J. Agronomy \& Crop Science, 190, 191-196.

Derpsch, R., Franzluebbers, A. J. , Duiker, S. W., Reicosky, D. C. , Koeller, K. , Friendrich, T., Sturny W. G. , Sa, J. C. M. and Weiss, K. (2014) Why do we need to standardize no-tillage research? Soil Till. Res. 137,16-22.

Dordas, C. A. (2010) Variation of physiological determinants of yield in linseed in response to nitrogen fertilization. Industrial Crops and Products, 31,455-465.

El-Deeb, I. A. E., Mohamed, N. A. and El-Kady, Eman A. E. (2006) Effect of seeding rates, planting methods and phosphorus fertilizers sources on yield and its components of Sakha 2 flax cultivar. Zagazig J. Agric. Res. 33 (1), 27-45.

El-Nagdy, G. A., Nassar, Dalia M. A., El-Kady, Eman A. and El-Yamanee, Gelan S. A. . (2010) Response of flax plant (Linum usitatissimum L.) to treatments with mineral and bio-fertilizers from nitrogen and phosphorus. Journal of American Science, 6 (10), 207-217.

Ernestein, O., Sayre, K., Wall, P. , Hellin, J. and Dixon, J. (2012) Conservation agriculture in maize-and wheat-based systems in the (sub) tropics: lessons from adaptation initiatives in South Asia, Mexico and Southern Africa, J. Sustain Agric. 36, 80-206.

Foulk, J. A., Bauer, P. J., Akin, D. E. , Busscher, W. J., Camp, C. R. , Ayala-Silva, T. and Dodd, R. B. (2007) Effect of tillage on double-cropped flax/ cotton production and fibre properties. Online, Crop Management doi: 10.1094/CM-2007-080301-RS.

Franke, A., Singh, S. , McRoberts, N. , Nehra, A. , Godara, S. , Malik, R. and Marshall, G. (2007) Phalaris minor seedbank studies: longevity, seedling emergence and seed production as affected by tillage regime. Weed Res. 47, 73-83.

Franzen, D. (2004)"Fertilizing Flax". North Dakota State University Fargo, North Dakota 58105, SF717.

Gomez, K. A. and Gomez, A. A. (1984) "Statistical Procedures for Agriculture Research". $2^{\text {nd }}$ ed. John Wiley and Sons, New York, USA.

Grant, C. A., Monreal, M. A., Irvine, R. B., Mohr, R. M., McLaren, D. L. and Khakbazan, M. (2008) Crop response to current and previous season applications of phosphorus as affected by crop sequence and tillage. Can. J. Plant Sci. 89, 49-66.

Heady, E.O. and Dillon, J.L. (1961) "Agricultural Production Function". Library of Congress Catalog card number: 60- 1128, Iwoa State University Press.

Hobbs, P. R., Sayre, K. and Gupta, R. (2008) The role of conservation agriculture in sustainable agriculture, Philos. Trans. R. Soc. B 363, 543-555.

Khajani, F. P., Irannezhad, H. , Majidian, M. and Oraki, H. (2012) Influence of different levels of nitrogen, phosphorus and potassium on yield and yield components of flax seed oil (Linum usitatissimum L.) variety Lirina. Journal of Medical Plants Research, 6 (6), 1050-1054.

Lafond, G. P., Grant, G. A. , Johnston, A. M. , Mc Andrew, D. W. and May, W. E. (2003) Nitrogen and phosphorus fertilizer management of no-till flax. Better Crops, 87 (1), 7-11.

Leilah, A. A., El-Kassaby, A. T., El-Hindi, M. H. and Abu-Zaid, T. A. (2003) Requirements of some flax 
cultivars from NPK fertilizers. Scientific Journal of King Faisal University, 4 (2), 125-139.

Mankowski, J., Pudelko, K. and Kolodziej, J. (2013) Cultivation of fiber and oil flax (Linum usitatissimum L.) in no-tillage and conventional systems. Part1. Influence of no-tillage and conventional system on yield and weed infestation of fiber flax and the physical and biological properties of the soil. Journal of Natural Fibers, 10 (4), 326-340.

Mankowski, J. and Pudelko, K. (2015) Evaluation of the effect of the tillage system and weed control on the yield of flax fibre and its quality. Fibres\& Textiles in Eastern Europe, 23, 3(111), 33-37.

Mousa, A. M. (2002) Effect of weed control on yield and quality for some genotypes in flax. M. Sc. Thesis, Fac. of Agric. Al-Azhar Univ.

Nalewaja, J. D. (2003) Weed and conservation agriculture, In: " Conservation Agriculture'L. Garcia-Torres et al. (Ed.), , pp. 201-210.

Nichols, V., Verhulst, N. , Cox, R. and Govaerts, B. (2015) Weed dynamics and conservation agriculture principles: A review. Field Crops Research, 183, 56-68.

Osman, M. S., Okaz, A. M., Hassanein, E. E. and El-Ninny, E. M. (2010) Effect of flax varieties, weed control methods under two different sowing methods on weeds and flax crop and its quality. Egypt. J. Agric. Res. 88 (4), 1293-1309.

Pittelkow, C. M., Linquist, B. A., Lundy, M. E., Liang, X., van Groenigen, J. K., Lee, J., van Gestel, N., Six, J., Venterea, R. T. and van Kessel, C. (2015) When does no-till yield more? A global metaanalysis. Field Crop Research, 183, 156-168.

Ruisi, P., Saia, S. , Badagliacca, G., Amato, G. , Frenda, A. S., Giambalvo, D. and Di Miceli, G. (2016) Long-term effects of no tillage treatment on soil $\mathrm{N}$ availability, $\mathrm{N}$ uptake and $15 \mathrm{~N}$-fertilizer recovery of durum wheat differ in relation to crop sequence. Field Crop Research, 189, 51-58.

Thomas, A. G., Legere, A., Leeson, J. Y., Stevenson, F. C., Holm, F. A. and Gradin, B. (2010) Weed community response to contrasting integrated weed management systems for cool dryland annual crops. Weed Research, 51, 41-50.

Verhulst, N., Govaerts ,B., Verachtert, E., CastellanosNavarrete, A., Mezzalama, M., Wall, P., Chocobar, A., Deckers, J. and Sayre, K. (2010). Conservation agriculture, improving soil quality for sustainable production systems. In: "Advances in Soil Science: Food Security and Soil Quality", Lal. R. Stewart, B. A. (Ed.), pp. 137-208. 


\section{تأثير كثافة الخدمة ، التسميد النيتروجينى والفوسفاتى والبوتاسى ومكافحة الحشائش على المحصول ومكوناته فى الكتان النيان}

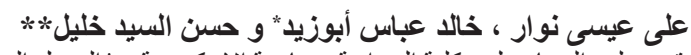

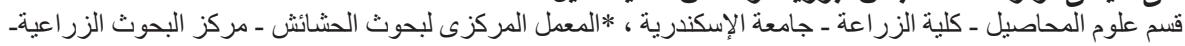

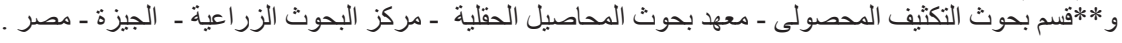

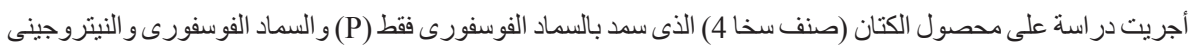

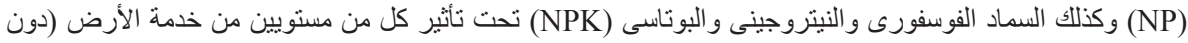

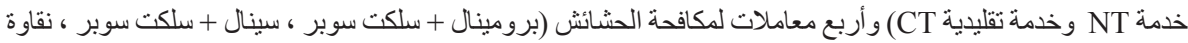

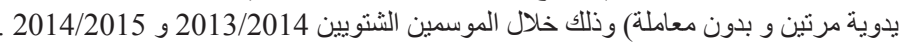

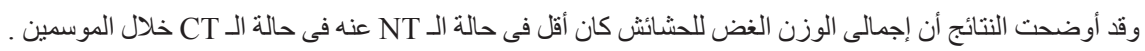

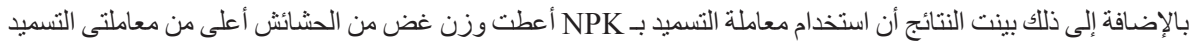

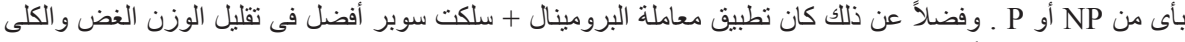

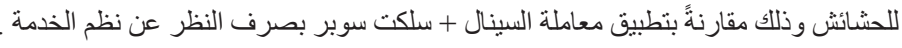

أما بالنسبة لصفات نمو نبات الكتان أوضحت النتائج فرق فى انتاج البذور عندما تم تطبيق نظام عدم الخدمة

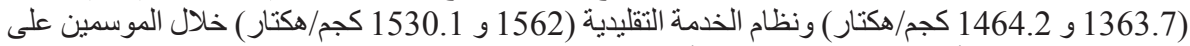

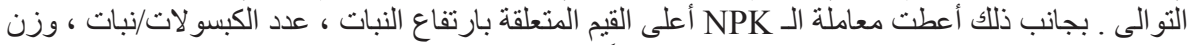

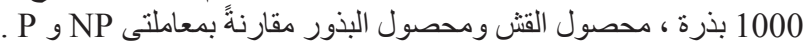

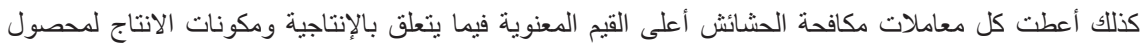

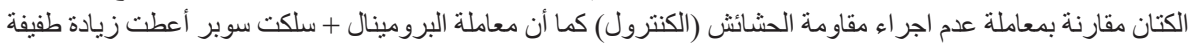

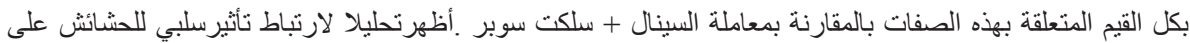
نموو إنتاجية الكتان .

دلت هذه الدر اسة على أن تطبيق زر اعة الكتان بدون اجراء عملية الخدمة كان مكافئاً لها تطبيق الخدمة التقليدية فيما

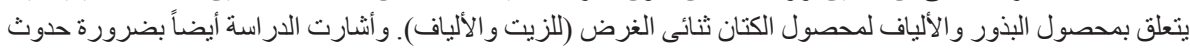

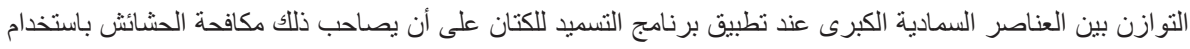
مبيدات الحشائش بعد الانبثاق لتحقيق انتاجية مرتفعة من الكتان . 